\title{
Estimating emission from gas power plant in palembang, indonesia using direct and indirect methods
}

\author{
Gabriel Andari Kristanto ${ }^{1, *}$, Alditho Farrasi Anantoputra ${ }^{1}$ \\ ${ }^{1}$ Civil Engineering Department, Faculty of Engineering, Universitas Indonesia, Depok 16424, Indonesia
}

\begin{abstract}
Nowadays, almost every daily activity is supported by the availability of energy, especially electricity. As the Borang $60 \mathrm{MW}$ Gas Power Plant in Palembang, Indonesia emits air pollutants such as $\mathrm{SO}_{2}, \mathrm{NO}_{\mathrm{x}}, \mathrm{CO}$, and total particulate matter (total PM), an emission inventory needs to be developed. Various methods can be used in the inventory of emissions; among others are a direct method based on direct measurement and an indirect method which involves the calculation of total emissions by emission factor. This study aims to estimate the emissions from the gas power plant in Palembang using direct and indirect methods and analyze the most suitable emission factor for Indonesian conditions. The comparison between emissions measured by direct and indirect methods found that the indirect method using the emission factor of AP-42 gives more accurate results for $\mathrm{SO}_{2}$ and $\mathrm{NO}_{\mathrm{x}}$, whereas the total emission of $\mathrm{CO}$ is more accurately calculated based on the indirect method using the emission factor developed by Kurokawa et al. (2013); the median value of total PM is more accurately calculated based on the indirect method using the emission factor developed by the IPCC.
\end{abstract}

\section{Introduction}

Nowadays, almost every daily activity is supported by the availability of energy, especially electricity. According to the electricity provider in Indonesia, PT PLN, every year the demand for electricity increases 3.6\% (Neraca Ekonomi Daily, April 16, 2015). Consequently, the Indonesian government built steam/gas power plants in many regions in Indonesia. Under the stated-own company, PT Wijaya Karya, Tbk., the Power Plant Borang (PPB) located in the area of Palembang was built to meet the electricity needs of South Sumatra area.

At the PPB, the air quality is monitored daily using the Continuous Emissions Monitoring System (CEMS) technology. To monitor continuously and efficiently, it is crucial to develop strategies and action plans for the management of air quality for the future such as identifying the source and amount of pollutants, known as emissions inventories [1]. Emissions inventories can be used to estimate critical emissions for the development of emission control strategies, determine licensing and control programs, ensure appropriate source impacts and mitigation strategies, and support other related applications by multiple users. The inventory itself is a database that lists the number of air pollutants released into the atmosphere in an area over a period of time based on the source [2].

An emission inventory is carried out with reference to the emission factors of generated air pollutants based on the types of exhaust gas-emitter technologies and how to control the emissions based on types of exhaust emitters. Various methods can be used in the inventory of

\footnotetext{
*corresponding author : andari@eng.ui.ac.id
}

emissions; among others are a direct method based on direct measurement and an indirect method which involves the calculation of total emissions by emission factor [3].

The emission factor is a representative value that describes the correlation between the quantity of a pollutant released to the atmosphere and the activity associated with the release of the pollutant [4]. These factors are usually expressed as the weight of the pollutant divided by the unit weight, volume, distance, or duration of activity that emits the pollutant [4]

The combustion technology used in PPB is a gas turbine (LM6000PC-General Electric). According to the Indonesian Ministry of Environment Regulation No. 12 of 2012, the gas turbine is the source of internal combustion emissions, where internal combustion generates heat as a direct propulsion of the engine/equipment. There are three main gas emissions generated by the PPB. The Sulphur dioxide $\left(\mathrm{SO}_{2}\right)$ emissions directly are related to the sulfur content in the fuel [5]. The higher the sulfur content in the fuel, the higher the $\mathrm{SO}_{2}$ gas emissions and vice versa. $\mathrm{CO}$ is also generated as a result of incomplete combustion. This gas is formed when the residence time is not sufficient at high temperatures or the mixing process is incomplete to accomplish the final step of oxidation of carbon fuel ( $\mathrm{CO}$ to $\left.\mathrm{CO}_{2}\right)$. Finally, nitrogen oxides $\left(\mathrm{NO}_{\mathrm{x}}\right)$ compounds occur in the gas turbine, being formed through three mechanisms: thermal $\mathrm{NO}_{\mathrm{x}}$, prompt $\mathrm{NO}_{\mathrm{x}}$, and $\mathrm{NO}_{\mathrm{x}}$ fuel. Particulate emissions from the turbine are caused by the release of non-combustible constituents in fuel.

This study aims to estimate the total emissions from the PPB using the indirect method based on different emission factors and comparing them to the direct 
measurement based on the CEMS data. This comparison can indicate an appropriate emission factor that is more suitable for Indonesian conditions.

\section{Research Methodology}

The study was conducted at the Gas Power Plant 60 BW Borang Unit 1, Banyuasin, South Sumatera (PPB). During the study, air pollutants analyzed include $\mathrm{SO}_{2}$, $\mathrm{NO}_{\mathrm{x}}, \mathrm{CO}$, and total PM. All air pollutants data were collected by CEMS in 2015. The input energy for the gas turbine is natural gas.

During this study, all pollutant data were recorded and the energy input of natural gas was analyzed using the following statistical analysis: outlier value test Dixon test, box and whisker plots and descriptive statistic test in Microsoft Excel 2013. The Dixon test was performed to eliminate high and low extreme values from each dataset to create a normal dataset. Furthermore, the descriptive statistical test was performed to determine the maximum, minimum, median, and average value of each pollutant in 2015.

Two methods were applied for estimating the total emissions from PPB: direct measurement using CEMS data and indirect measurement using three emission factors.

Calculation of the total emission of each pollutant $\left(\mathrm{SO}_{2}, \mathrm{NO}_{\mathrm{x}}, \mathrm{CO}\right.$, and total $\left.\mathrm{PM}\right)$ using direct measurement was conducted using the methodology mentioned in the Indonesian Ministry of Environment Regulation No. 21 of 2008 on the standard of uninterrupted source of emissions for business and/or thermal power generation:

$$
\begin{gathered}
E=C \times Q \times 0.0036 \times[\text { Op Hours }] \\
Q=v \times A
\end{gathered}
$$

where $\mathrm{E}$ is pollutant emission rate ( $\mathrm{kg} /$ year); $\mathrm{C}$ is concentration $\left(\mathrm{mg} / \mathrm{Nm}^{3}\right) ; \mathrm{Q}$ is emissions flow rate ( $\mathrm{m}^{3} /$ second); Op Hours is hours of plant operation for 1 (one) year; $\mathrm{v}$ is flow rate ( $\mathrm{m} / \mathrm{second})$; $\mathrm{A}$ is stack sectional area $\left(\mathrm{m}^{2}\right)$.

To calculate the total emissions of each pollutant per year, the value of the volumetric emission flow rate (Q), either the average $\mathrm{Q}$, the maximum $\mathrm{Q}$, or the minimum $\mathrm{Q}$, is needed. The area of the stack section (A) is $3 \mathrm{~m}^{2}$. The A36 material (carbon steel stack) has a diameter of $2 \mathrm{~m}$ with a height of $17 \mathrm{~m}$. The velocity (v) used is the average $\mathrm{v}$, minimum and maximum $\mathrm{v}$. The fuel usage value per year of PPB is $12,499.24 \mathrm{MMBtu} /$ year.

Indirect total emissions of each pollutant $\left(\mathrm{SO}_{2}, \mathrm{NO}_{\mathrm{x}}\right.$, $\mathrm{CO}$, and total $\mathrm{PM}$ ) were calculated based on emission factors from various sources (AP-42, IPCC, and Kurokawa et al.). The formula applied for the calculation is based on the Indonesian Ministry of Environment Regulation No. 12 of 2012 on guidelines for the calculation of total emissions of oil and gas industry activities:

$$
\begin{gathered}
F C=E I \times \frac{1}{H V} \\
E, n=F C \times E F
\end{gathered}
$$

where $\mathrm{FC}$ is fuel consumption per year (MMBtu/year); EI is Energy input (MMBtu/year); $\mathrm{HV}$ is heating value (Btu/scf); E, $\mathrm{n}$ is component emission in $(\mathrm{kg}) ; \mathrm{n}$ is emission parameters $\left(\mathrm{CO}, \mathrm{PM}, \mathrm{NO}_{\mathrm{x}}, \mathrm{SO}_{2}\right)$, and $\mathrm{EF}$ is emission factor. Prior to the calculation, the EI and HV values used have been tested with the outlier values test and descriptive statistical tests.

Comparison of the total emission value of each pollutant based on direct and indirect methods is expressed by using the following formula

$$
\%=\left|\frac{B_{n}-A}{A}\right| \times 100 \%
$$

where $B_{n}$ is total emission based on indirect methods, $n$ is emission factor from $\mathrm{n}$ source, and $\mathrm{A}$ is the total emission

\begin{tabular}{|c|c|c|c|}
\hline \multirow[b]{2}{*}{ Pollutant } & \multicolumn{2}{|c|}{ AP-42 } & \multirow{2}{*}{$\begin{array}{c}\text { Total } \\
\text { Emission } \\
\text { (kg/year) }\end{array}$} \\
\hline & $\begin{array}{c}\text { Emission Factor } \\
\text { (lb/MMBtu) }\end{array}$ & Rating & \\
\hline $\mathrm{SO}_{2}$ & 0.0034 & B & 19.28 \\
\hline $\mathrm{NO}_{\mathrm{x}}$ & 0.32 & A & 1814.26 \\
\hline $\mathrm{CO}$ & 0.082 & $\mathrm{~A}$ & 464.9 \\
\hline Total PM & 0.0066 & $\mathrm{C}$ & 37.42 \\
\hline
\end{tabular}
of each pollutant based on the direct method (average, maximum, and minimum).

Table 1. Total emissions of air pollutants based on the AP-42 emission factors

Table 2. Total emissions of air pollutants based on the IPCC emission factors

\begin{tabular}{|l|c|c|}
\hline \multirow{2}{*}{ Pollutant } & IPCC & \multirow{2}{*}{$\begin{array}{c}\text { Total Emission } \\
\text { (kg/year) }\end{array}$} \\
\cline { 2 - 2 } & $\begin{array}{c}\text { Emission Factor } \\
\text { (kg/MMBtu) }\end{array}$ & \\
\hline $\mathrm{SO}_{2}$ & 0.00067 & 8.33 \\
\hline $\mathrm{NO}_{\mathrm{x}}$ & 0.2005 & 2505.61 \\
\hline $\mathrm{CO}$ & 0.0485 & 606.62 \\
\hline Total PM & 0.0027 & 34.0053 \\
\hline
\end{tabular}

Table 3. Total emissions of air pollutants based on the Kurokawa et al. emission factors

\begin{tabular}{|l|c|c|}
\hline \multirow{2}{*}{ Pollutant } & Kurokawa et al. & \multirow{2}{*}{$\begin{array}{c}\text { Total Emission } \\
\text { (kg/year) }\end{array}$} \\
\cline { 2 - 2 } & $\begin{array}{c}\text { Emission Factor } \\
\text { (lb/MMBtu) }\end{array}$ & 3.23 \\
\hline $\mathrm{SO}_{2}$ & 0.00057 & 2703.42 \\
\hline $\mathrm{NO}_{\mathrm{x}}$ & 0.48 & 270.34 \\
\hline $\mathrm{CO}$ & 0.048 & 0 \\
\hline Total PM & 0 & \\
\hline
\end{tabular}

\section{Results}

Calculation of total emissions of each pollutant based on direct measurement using CEMS data was conducted 
using formulas (1) and (2). The results are presented in Figs. 1 - 4. The total emission for each pollutant was calculated based on the emission factor method using formulas (3) and (4). The AP-42 emission factor was used in this study because it is used by the Indonesian Ministry of Environment as a gas turbine emission factor in Indonesia. Inter Governmental panel on Climate Change or IPCC is an emission factor that is also used in many countries. The emission factor developed by Kurokawa et al. was used since it represents the condition in Asian region [6]. The calculation of the total emission of each pollutant using the indirect method of emission factors is presented in Tables 1-3.

Direct and indirect measurements of total emissions of each air pollutant are presented graphically in Figures 1 to 4 as follows:

1. $\mathrm{SO}_{2}$

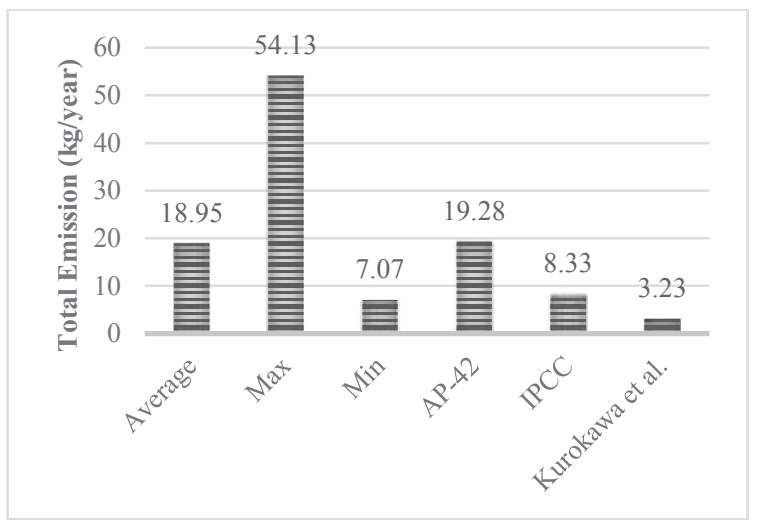

Fig. 1. Total $\mathrm{SO}_{2}$ emissions based on direct and indirect methods

2. $\mathrm{NO}_{\mathrm{x}}$

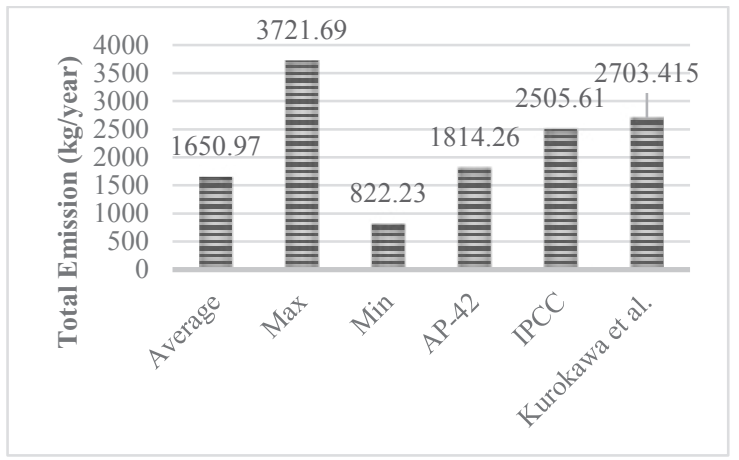

Fig. 2. Total $\mathrm{NO}_{\mathrm{x}}$ emissions based on direct and indirect methods

3. $\mathrm{CO}$

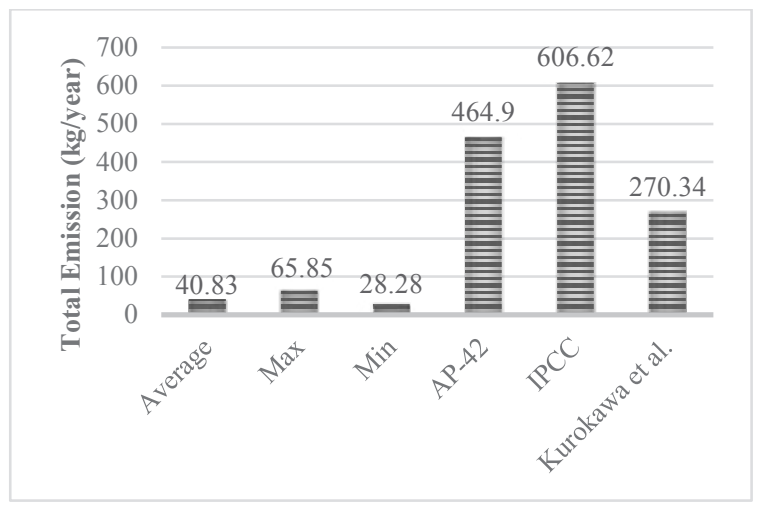

Fig. 3. Total $\mathrm{CO}$ emissions based on direct and indirect methods

\section{Total PM}

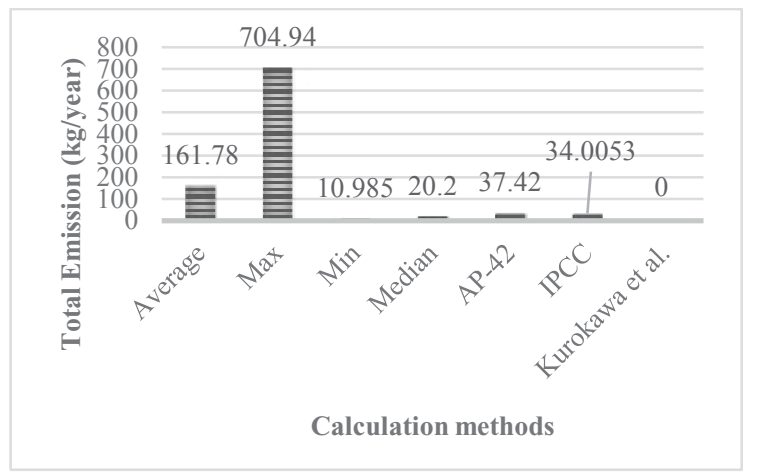

Fig. 4. Total PM emissions based on direct and indirect methods

This study showed that the amount of total emission of each pollutant is highly dependent on the emission factor used during the calculation. Several factors affect these results such as omitted outlier value and the emission factor used.

\subsection{Omitted Outlier Value}

Based on statistical requirements, the test is used to normalize abnormal data sets based on the normality test, to detect the presence of any data that have variations far different from other data, but data removal may also affect the assessment and environmental analysis of the actual condition of the gas power plant and the gas turbine itself. For example, data on high emissions could be due to air pollution control systems that did not function properly or were being repaired and thus could not be omitted.

\subsection{Comparison of Total Emission Loads by using Direct and Indirect Methods}

Results of total emissions of each air pollutant $\left(\mathrm{SO}_{2}, \mathrm{NO}_{\mathrm{x}}\right.$, $\mathrm{CO}$, and $\mathrm{PM}$ ) showed a significant difference between direct and indirect methods not only for maximum and minimum, but also average values. However, the closest average of total emissions calculated by the direct measurement is very similar to AP42 for $\mathrm{NO}_{\mathrm{x}}$ and $\mathrm{SO}_{2}$. The gas heating value is not much different between AP- 
42 and direct methods, which are $1020 \mathrm{Btu} / \mathrm{cf}$ and 1026.855 Btu/cf respectively. Previous studies mentioned that the small differences of gas heating value can cause similarities of total emission of $\mathrm{NO}_{x}[3]$.

Previous studies stated that AP-42 emission factors are more accurate for calculating pollutants of non-GHG emissions, which are $\mathrm{CO}$ and $\mathrm{NO}_{\mathrm{x}}[3,7]$ pollutants. Their findings also confirmed the same results for the average $\mathrm{NOx}$, but not for $\mathrm{CO}$. The result of $\mathrm{CO}$ emissions calculated by the indirect method is much higher than by the direct method.

In this current study, the median value of total emissions of total PM is similar to the total emission calculated using emission factors of AP-42 and IPCC. This means that although the rating of AP42 emission factor for total PM is C, which is medium, this study shows that AP-42 is reliable enough to be used as an emission factor for the median value of total PM emission inventory.

The United Nations stated that developing countries generally use AP-42 emission factors as their tool for emission inventory (United Nations, 2007). For example, the Indian inventory of emissions from industrial areas and fuel combustion and the Malaysian Emission Factor for Tropical Peatlands Drained for Oil Palm Cultivation also use AP-42 [9, 10]. It is suggested that developing the emission factor suitable for each country's condition is preferable.

\subsection{Decision Making Related to Total Emissions Generated}

Total emissions throughout the year can be used as reference for air pollution control operations. Understanding the pattern of emissions throughout the year will not only be beneficial in protecting the environment but also affect the overall cost of PPB operation.

\subsection{Conditions in Indonesia}

The consumption of natural gas as the main fuel for power generation in Indonesia is far behind many countries where the sources of emission factors originate. In 2015, the use of natural gas in Indonesia reached $38 \times 106$ MMBtu, while in the same year, the United Stateswhere the AP-42 emission factors originated-consumed $28,116 \times 106$ MMBtu of natural gas; the OECD Europe (Organization for Economic Co-operation and Development - Europe) comprising several European countries - the region of origin of the IPCC emission factors - consumes 16,905 × $106 \mathrm{MMBtu}$ of natural gas; China, where the Kurokawa et al. emission factors were developed, consumes $6,858 \times 106 \mathrm{MMBtu}$ of natural gas $[11,12]$.

\section{Conclusions}

This present study compared between total emission based on direct and indirect method. It was found that the indirect method using the AP-42 emission factors gives better result for $\mathrm{SO}_{2}$ and $\mathrm{NO}_{\mathrm{x}}$, whereas the total emission of $\mathrm{CO}$ is more accurately calculated based on indirect calculation using the emission factors developed by Kurokawa et al. [6]; total PM is more accurately calculated in median value based on indirect calculation using the emission factors developed by the IPCC.

Authors would express their gratitude for the financial support of the present work by PITTA scheme for budget year 2018. The scheme was granted by Universitas Indonesia.

\section{Refference}

1. Indonesia Ministry for environment. 2012. Emission Inventory. Available on line on http://www.menlh.go.id/DATA/csr_pi_2012/do wnload/DRAFT\%20FINAL\%20PEDOMAN\% 20TEKNIS $\% 20$ PENYUSUNAN\%20INVENT ARISASI\%20EMISI\%20(1).pdf Acessed on July 02, 2017.

2. Xu, Y., et al. (2017). Current and Future Emissions

of Primary Pollutants from Coal-Fired Power Plants in Shaanxi, China. Science of the Total Environment, 595, pp. 505-514.

3. Zhao, Y., et al. (2010). Establishment of a Database of Emission Factors for Atmospheric Pollutants from Chinese Coal-Fired Power Plants.Atmospheric Eironmennt, 44(22), Pages 1515-1523.

4. USEPA. (1995). Section 5.2 Post-Combustion Controls. Available on https://www.epa.gov/sites/production/files/2015

07/documents/chapter_5_emission_control_tec hnologies.pdf Acessed on September 06, 2017.

5. Soares, C. (2007). Gas Turbines : A Handbook of Air, Land, and Sea Applications. London: Elsevier Science.

6. Martin, A. et al. Exergy Analysis of Gas Turbine Power Plant $20 \mathrm{MW}$ in Pekanbaru-Indonesia. 2017. International Journal of Technology, v. 7, n. 5, p. 921-927.

7. Kurokawa, J., et al. (2013). Emissions of Air Pollutants and Greenhouse Gases over Asian Region during 2000-2008: Regional Emission Inventory in Asia (REAS) Version 2.

8. Lewis, M.P. 2009.Estimating Fuel Use of Nonroad Diesel Construction Equipment Performing Representative Duty Cycles. Ph.D Dissertation, North Carolina University Raleigh, NC.

9. Gargava, P., \& Aggarwal, A. L. (1999). Emission Inventory for an Industrial Area of India, Emmission Monitoring and Assessment, Vol 55(2), pp 299-304. 
10. USEPA. 2014. Available on https://www.epa.gov/sites/production/files/2016 -07/documents/climateindicators-full-2014.pdf Acessed on June 28, 2017.

11. PWC. (2016). Power in Indonesia: Investment and Taxation Guide, November 2016 - 4th Edition.

12. Swiss Singapore Overseas Enterprises PTE Ltd. (2016). China: Coal vs Natural Gas. 